\title{
Understanding the Biology of Glaucoma: The Current Scenario
}

\author{
${ }^{1}$ Sarangapani Sripriya, ${ }^{2}$ Ronnie George, ${ }^{2}$ Lingam Vijaya, ${ }^{1}$ Govindasamy Kumaramanickavel \\ ${ }^{1}$ SNONGC Dept of Genetics and Molecular Biology, Vision Research Foundation \\ ${ }^{2}$ Dept of Glaucoma, Medical Research Foundation \\ Sankara Nethralaya, India \\ e-mail: gkumarmvel@gmail.com
}

\section{INTRODUCTION}

Glaucoma is the second leading cause of blindness in the world. Family history is one of the major risk factors for glaucoma and heritability estimates have shown that there is 3.7 times higher risk to develop the disease for the siblings than the general population. Linkage analysis of large POAG families with Mendelian inheritance has identified different loci that have been corroborated in different populations. Still this contributes only to a very small proportion of glaucoma genes that are yet to be identified. Due to the complex etiology of the disease, the role of multiple interacting factors including genetic loci have been suspected. Alternative approaches like quantitative trait loci mapping, animal models studies, etc. that overcome the limitations of the standard approach for gene identification would help in identifying multiple interacting loci that contributes to major susceptibility factors. In this review we focus on the different genes that are linked to glaucoma, newer approaches and their outcome.

The WHO statistics on global blindness have shown that 167 million people worldwide are visually impaired and the majority of these diseases are complex diseases accounting for $\sim 67$ percent of global blindness (cataract: $47.8 \%$; glaucoma: 12.7\%; age related macular degeneration: $8.3 \%$ ) and glaucoma stands second in the list. Glaucoma is clinically asymptomatic, where the patients experience a painless progression of vision loss noticed usually at the end stages of the disease resulting in irreversible visual damage. ${ }^{1}$

Glaucoma is classified into primary and secondary according to the etiology. Based on the angle configuration, glaucoma is classified as primary open-angle (POAG) and closed-angle (PACG). A functional defect in the trabecular meshwork results in POAG while a closed/narrow iridocorneal angle (junction between iris root and cornea occurring at the periphery of the anterior segment of the eye) obstructs the normal aqueous humor outflow in PACG. NTG is another type of glaucoma in which the pressure remains within the normal limits (21 mm Hg) but nevertheless optic nerve degeneration occurs. Primary glaucomas can be congenital, juvenile or late onset according to the age of onset of the disease. The pediatric form of glaucoma is seen from birth till the age of 3 years while juvenile glaucoma arises between 3 and 20 years age. The late onset form of POAG and PACG occurs after the age of 40 years.

\section{HERITABILITY OF GLAUCOMA AND ASSOCIATED RISK FACTORS}

Genetic predisposition represents a major risk for glaucoma as per the prevalence rate of glaucoma in first-degree relatives of POAG patients, which is as much as eight times higher than the general population. The siblings of glaucoma patients have 3.7 time higher risk for the disease. The different clinical physiological parameters for glaucoma, namely the intraocular pressure (IOP), cup-disk ratio (CDR), ${ }^{2}$ etc. are linked to chromosomal loci 10q22 and 1p32, respectively. A report on the familial aggregation and heritability of risk factors for POAG by the Beaver Dam Eye study ${ }^{3}$ has shown habitability estimates of $0.36,0.55,0.57$, and 0.48 for the POAG risk determining factors, namely the IOP, optic cup and disc diameter, and CDR, respectively. Similarly, the familial correlation for POAG among different relations, namely sibling pairs, parent-child and cousin pairs for IOP are reported to be statistically significant. These observations indicate that the risk factors for POAG genetically segregate in families; thus, confirming the hypothesis that there are genetic determinants for glaucoma. ${ }^{3}$ Ethnic differences also contribute to the risk for glaucoma, while POAG is more common in the Western countries; PACG is predominantly reported in the Chinese, ${ }^{4}$ Asian Indians ${ }^{5}$ and Africans. ${ }^{6}$

A strong genetic predisposition has been observed for the anatomical and physiological risk parameters for PACG. In the year 1953, Tornquist et al first suggested that an autosomal dominant gene transmits PACG. ${ }^{7}$ Later in 1975, studies on PACG 
families have shown an increased prevalence of PACG among the sibs of the proband. ${ }^{8}$ Heritability of 70 percent has been observed for the axial anterior chamber depth (ACD) by biometric studies in PACG families that indicated that about two-thirds of the age and sex independent variation in ACD could be genetic. ${ }^{9}$ It has been observed that the Eskimos have shallow ACD. The 1st and 2nd degree relatives of the PACG patients are observed to have a relatively shallow chamber; thus, emphasizing a strong role for genetic factors in the pathology of the disease. ${ }^{9}$ Thus, there are ample evidences on strong genetic predisposition for PACG but the susceptibility of genes are yet to be identified.

\section{INHERITANCE OF GLAUCOMA}

Glaucoma can be inherited as a Mendelian (single gene disorder) or complex trait; however, a single report on possible involvement of mitochondria in POAG pathology also exists. The early onset forms of glaucoma, i.e. congenital, juvenile or developmental syndromes like nail-patella, aniridia, AxenfeildReiger, pigment dispersion syndrome are inherited as autosomal dominant or recessive traits. A major proportion of glaucoma occurring secondary to other ocular conditions exhibit autosomal recessive inheritance. The adult onset glaucomas including angle-closure glaucoma, normal/low tension glaucoma, psuedoexfoliation glaucoma, etc. are inherited as complex traits.
A recent report has proposed a newer classification of glaucoma as inherited, familial, and sporadic. Inherited POAG is classified based on presence of more than 3 affected members in the family including the proband and at least one affected first degree relative in more than 2 consecutive generations. The familial POAG involves $>2$ first and/or second degree relatives and does not follow the criteria for isolated case. Sporadic POAG involves a single patient without affected firstor second-degree relatives. ${ }^{10}$

\section{CONCEPTS IN GENETIC DISSECTION OF GLAUCOMA}

Broadly, the strategies for disease gene identification could be classified as positional and functional cloning methods. In the positional dependent approach, the chromosomal location of the gene of interest is identified by family-based linkage studies and the candidate gene is screened for pathogenic mutations in patients with the disease in question. In functional approach, the disease gene is identified through the knowledge on the protein product. Linkage, association studies, candidate gene analysis and animal models have significantly contributed to our current knowledge in glaucoma genetics (Table 1).

The most common type of glaucoma, POAG has different etiology, namely functionally defective trabecular meshwork due to altered extracellular matrix remodulation, imbalance in the antioxidant defense system or immune reactions. Out of the

Table 1: Genes/chromosomal loci for glaucoma

\begin{tabular}{lll}
\hline OMIM symbol/number & Chromosomal loci & Genes \\
\hline POAG & & - \\
GLC1B/\%606689 & 2cen-q13 & - \\
GLC1C/\%601682 & $3 \mathrm{q} 21-\mathrm{q} 24$ & - \\
GLC1D/\%602429 & $8 \mathrm{q} 23$ & OPTN \\
GLC1E/\#137760 & $10 \mathrm{p} 15-14$ & - \\
GLC1F/*603383 & $7 \mathrm{q} 35-36$ & WDR36 \\
GLC1G/\#609887 & $5 \mathrm{q} 21.3-\mathrm{q} 22.1$ & - \\
GLC11/\%609745 & $15 \mathrm{q} 11-13$ & \\
JOAG & & MYOC \\
JOAG1/\#137750 & $1 \mathrm{q} 24-25$ & CYP1B1 \\
JOAG1/\#137750 & $2 \mathrm{p} 22-21$ & LXM1B \\
JOAG1/\#137750 & $9 \mathrm{q} 34.1$ & - \\
GLC1J(JOAG 2)/\%608695 & $9 \mathrm{q} 22$ & - \\
GLC1K(JOAG3)/\%608696 & $20 \mathrm{p} 12$ & \\
$N T G$ & & OPTN \\
\#606657 & $10 \mathrm{p} 15-\mathrm{p} 14$ &
\end{tabular}

Contd... 


\begin{tabular}{|c|c|c|}
\hline OMIM symbol/number & Chromosomal loci & Genes \\
\hline \#606657 & 3q28-p29 & OPA1 \\
\hline \multicolumn{3}{|l|}{ PCG } \\
\hline GLC3A/\#231300 & 2p22-p21 & CYP1B1 \\
\hline GLC3B/\#600975 & 1p36.2-p36.1 & - \\
\hline \multicolumn{3}{|l|}{ Developmental glaucoma } \\
\hline Reiger syndrome (RIEG1)/ \#180500 & $4 q 25$ & PITX2 \\
\hline Iridogoniodysgenesis syndrome (IRID2)/ \#137600 & $4 q 25$ & PITX2 \\
\hline Nail Patella syndrome/602575 & $9 q 34$ & LM1B \\
\hline Iridodysgenesis type 1 (IRID1)/ 601631 & $6 p 25$ & FOXC1 \\
\hline Pigment disperson syndrome/\%600510 & $7 q 35-36$ & GPDS1 \\
\hline Nanophthalmos (NNO1)/ \%600165 & $11 \mathrm{p}$ & - \\
\hline Aniridia (AN2)/ \#106210 & $11 \mathrm{p} 13$ & PAX6 \\
\hline Nanophthalmos (NNO2)/ \#609549 & $11 q 23$ & MFRP \\
\hline Rieger syndrome/\%601499 & $13 q 14$ & RIEG2 \\
\hline
\end{tabular}

7 chromosomal loci linked to glaucoma, 3 genes (myocilin, optineurin and WDR 36) have been characterized and studied across different populations. However, owing to the clinical and genetic heterogeneity of the disease, these genes are shown to depict a wide spectrum of possible disease causing mutations. However, the knowledge on the genetics of glaucoma is still sparse and the role played by these three genes is relatively small compared to the magnitude of the disease. The review focuses on the different genes characterized by family-based studies, candidate gene approach and animal models.

\section{CANDIDATE GENES FOR POAG}

\section{Myocilin}

Myocilin (MYOC) gene, that was first mapped in a JOAG family $^{11}$ to chromosomal loci 1q24.3-q25.2 and later to POAG ${ }^{12}$ is responsible for 3 to 5 percent of glaucoma worldwide. The gene ranges up to $20 \mathrm{~kb}$ with a $5 \mathrm{~kb}$ promoter region that contains 13 hormone response elements including several glucocorticoid regulatory elements and has 3 exons of 604, 126, and 782 bp sizes. $^{12}$ The gene is expressed as a $2.3 \mathrm{~kb}$ transcript in both ocular and nonocular tissues like the heart, skeletal muscle, stomach, thyroid, trachea, bone marrow, thymus, prostate, small intestine and colon. In the eye, MYOC is expressed in the tissues involved in aqueous humor regulation such as the ciliary body, iris, lamina cribrosa, TM and also in the retina, sclera, cornea, and optic nerve head. The protein was initially localized in the ciliary rootlet and basal body of the connecting cilium of photoreceptor cells. Extensive studies on the molecular localization of the protein have shown that it is a secretary protein localized intracellularly in the trabecular cells and cilia of the photoreceptor cells. Immunological labeling of the ECM components in the trabecular lamellae, juxta-canalicular tract and corneoscleral meshwork has shown that the protein localizes to the basement membrane in the long space of collagen and elastin fibers that are increased in POAG patient's eyes. ${ }^{13}$

The protein is secreted as a $58 \mathrm{kDa}, 504$ amino acid protein with a leucine zipper domain, 10 putative phosphorylation sites, and 4 potential glycosylation sites and exists in two forms: glycosylated (55 kDa) and unglycosylated (66 kDa), ${ }^{14}$ with two main domains: coiled domain in the N-terminus and an olfactomedin domain near the C-terminus. The protein colocalizes with the ECM component fibronectin thus suggesting a possible role in ECM regulation. ${ }^{15}$

The majority of the 73 disease causing mutations reported till date are found in exon 3 that codes for the olfactomedin domain of the protein ${ }^{16}$ and are reported in 3 to 5 percent of isolated adult-onset POAG and 36 percent of patients with early onset glaucoma in different ethnic populations. These mutations are well correlated with clinical features, namely age of onset (P370L, Tyr437His and Ile477Asn), response to medications (E323K), IOP (Gln368Stop) in various studies. ${ }^{17}$ Some of these mutations are also population-specific (Gly252Arg, Gly367Arg and Pro370Leu mutations specific to Asians and Caucasians; Thr293Lys, Thr377Met and Glu352Lys mutations in Africans and Caucasians; Q48H in Indians). ${ }^{18-20}$ These mutations are suggested to result in the accumulation of truncated protein in the cells and reduce the secretion of endogenous MYOC; misfolding of the protein that interfere in protein trafficking through cellular pathways and are proposed to result in the 
pathology by gain of function mechanism. Caballero et al has observed through cell culture studies that the solubility property of the WT protein in nonionic detergents is lost in the mutant protein. ${ }^{21}$ The mutant protein has been shown to be retained within the cell thus resulting in deleterious effect on the cell. ${ }^{22,23}$ Thus retained mutant protein might interact with the normal protein and prevent the expression of the same as shown by cell culture studies. ${ }^{21}$

Studies have also shown that mutant MYOC were misfolded and forms heavy aggregates accumulating in the endoplasmic reticulum that might result in abnormal cell morphology and death. ${ }^{23}$ Such mechanism in vivo would result ultimately in increased IOP and finally glaucoma, thus, providing a plausible gain of function model for the mutant protein. ${ }^{24} \mathrm{~A}$ dominant negative model for glaucoma is also proposed for MYOC proteins with amino acid changes in the olfactomedin domain, where accumulation of the complexes formed between the WT and mutant MYOC protein leads to malfunctioning of the cells thus resulting in glaucoma. ${ }^{22}$ Another possible mechanism proposed for the pathological role of MYOC in glaucoma is through alteration of the TM ECM through its interaction with some of the ECM components like fibronectin. ${ }^{25}$

\section{Optinuerin}

Optic neuropathy protein (OPTN) gene located on the chromosomal region 10p15-14 with 16 exons coding for a 577 amino acid protein of $\sim 66 \mathrm{kDa}$ molecular weight (GLC1E) (OMIM: 602432). The gene was initially linked to 16.7 percent of NTG26 is shown to have a possible role in POAG and JOAG27 cases worldwide. The exact role of this protein is still not fully understood; however, it has been shown to interact with diverse proteins and thus called by different names: (i) TNFo inducible protein as it is induced by TNF $\alpha$ stimulation;, ${ }^{28}$ (ii) FIP 2 gene stimulated by the adenoviral protein E3-14.7K to inhibit the apoptosis mediated by TNF a and FasL receptors; ${ }^{28}$ (iii) TFIIIA interacting protein (TNFIIIA-INTP) as it interacts with transcription factor IIIA; ${ }^{29}$ (iv) NRP (NEMO $\left(\mathrm{NF}_{\mathrm{k}} \mathrm{B}\right.$ essential modulator)-related protein, ${ }^{30}$ since it acts as a structural and regulatory subunit of the high molecular weight kinase complex, essential for the $\mathrm{NF}_{\mathrm{k}} \mathrm{B}$ signaling pathway. The gene is expressed in the nonocular tissues like heart, brain, placenta, liver, skeletal muscle, kidney, and pancreas. In the eye it is expressed in TM tissue, nonpigmented ciliary epithelium, retina, etc. The OPTN protein interacts with different proteins involved in apoptosis, inflammation and vasoconstriction. ${ }^{31}$ A hypothetical model was derived for the function of the OPTN protein based on its interaction with different proteins that suggests a possible function for the protein through the TNF $\alpha$ and Fas ligand pathway. ${ }^{31}$ It is hypothesized that by restraining the availability of TNFa, which induces the synthesis of excessive neurotoxic nitric oxide in the optic nerve head astrocytes and glial cell leading to RGC death, the OPTN protein extends a neuroprotective role. Funayama et al showed a risk association for the interaction between TNF promoter polymorphisms and OPTN gene variants with development and progression of glaucoma. ${ }^{32}$ The OPTN protein is also speculated to cause vasoconstriction through the AA-P450 pathway. ${ }^{31}$ Eicosanoid, a metabolite of the AA pathway, is found to have direct effect in blood vessel constriction and ion transport that leads to reduced aqueous humor production and acts as one of the causes for the structural damages reported in NTG.

On analyzing different studies on OPTN gene analysis, it could be observed that predominant SNP variations are in either coding or non-coding region which has been observed in different ethnic population (Table 2). For example, the R545Q mutation reported initially as disease causing ${ }^{26}$ has been observed in equal frequency between the patients and controls in the Chinese ${ }^{33}$ and Japanese ${ }^{34}$ populations. The M98K variation is one such variation that showed strong risk correlation with glaucoma which probably is acting as a modifier of IOP. ${ }^{35,36}$ Later on studies from different ethnic populations showed that the sequence change was present in the unaffected healthy control (UHC) posing the query on the variation as just a polymorphism. The E50K mutation was also strongly correlated only in the NTG patients when compared to the controls thus acting as a predictive marker for early detection and prevention of vision loss. ${ }^{37}$ Even though results from many studies do not suggest any significant role for OPTN mutations in POAG, a strong correlation has been observed in certain ethnic groups. A possible role of OPTN gene in JOAG pathology ${ }^{27}$ was also observed on screening a cohort of 66 JOAG patients, in which 2 sequence changes (H486R and L42L SNP) were strongly associated with JOAG pathology. The SNP L42L was observed to have a profound effect on RNA structure and splicing.

The E50K mutation has been studied intensely for its possible effect on the protein function. Cell culture studies with the E50K mutant protein have shown decreased secretion of the protein suggesting dominant negative model 26 and alter the region of bZIP transcription factor domain. Studies by QCM have shown that the OPTN mutant protein is found to alter its interaction with RAB-8. While the interaction of the WT OPTN with the RAB-8 protein remains unchanged, the mutant protein completely abolishes the interaction. ${ }^{31}$ The RAB-8 protein has been shown to have a role in protein endocytosis and exocytosis but the exact mechanism by which it interacts with altered OPTN and causes glaucoma is yet to be studied. It is demonstrated recently by that the mutant protein (E50K) induces cell death of the RGCs selectively that could be prevented or delayed by the administration of antioxidants. ${ }^{38}$

With very few disease causing mutations identified, the role of mutant OPTN protein in POAG is not well understood. But various evidences by different techniques like bioinformatics modeling, QCM, etc. have shown that some of the nucleotide 
Understanding the Biology of Glaucoma: The Current Scenario

Table 2: Distribution of the OPTN sequence variants observed frequently in POAG and NTG patients worldwide

\begin{tabular}{clll}
\hline Exon & Variations & Ethnicity & Glaucoma \\
\hline 4 & E50K & Caucasian & POAG, NTG \\
5 & M98K & Caucasian & POAG \\
& & Japanese & POAG, NTG \\
5 & E103D & Chinese & POAG \\
6 & i AG & POAG & JOAG \\
14 & H486R & Canadian & POAG, NTG \\
7 & R545Q & Japanese & POAG \\
\hline
\end{tabular}

changes have potential effect on the RNA structure and thus on the OPTN protein function. ${ }^{31}$ There are few studies that have characterized the effect of mutant OPTN in glaucoma pathology. Studies on the effect of elevated IOP on OPTN expression by anterior chamber perfusion model of human eye did not show any variation in the protein levels thus suggesting that the OPTN protein is not involved in the aqueous humor outflow regulation. ${ }^{39}$ Thus, there is lack of consistent association of the disease with OPTN alleles that ultimately questions on the role of OPTN in glaucoma.

\section{WDR 36 (WD Repeat-containing Protein 36)}

The gene (chromosomal loci: 5q21.3-q22.1) codes for T-cell activation WD repeat-containing protein that is co-regulated with IL-2 has been linked to POAG. ${ }^{40}$ The gene is expressed in both ocular (heart, brain, placenta, lung, liver, skeletal muscle, kidney, and pancreas) and nonocular tissues (lens, iris, sclera, ciliary muscles, ciliary body, trabecular meshwork, retina, and optic nerve) as 5.9 and $2.5 \mathrm{~kb}$ transcripts. ${ }^{40}$ Till date 24 sequence variants were identified in this gene in POAG patients: Four were disease-causing (5\% of 130 POAG families and $0 \%$ of 200 control subjects), 3 as disease-predisposing (11\% of POAG families and $2 \%$ of control subjects), and 17 as polymorphisms (OMIM*609669). The protein has been proposed to involve in T cell activation in response to IL- $2 .{ }^{41}$ It is noteworthy that T cell mediated responses have been hypothesized to cause glaucoma associated optic nerve degenerations in human and mouse models. ${ }^{41}$ Previous studies have also suggested that some patients with glaucoma may have an alteration of cellular immunity that is IL-2 dependent. It was observed that patients with wild type $\mathrm{WDR}^{36}$ presented with elevated intraocular pressure without any significant changes in the optic nerve and visual field defects thus suggesting a possible modifier gene effect on the optic nerve degeneration.

\section{PRIMARY CONGENITAL GLAUCOMA}

This is a form of POAG occurring at very early age, mostly within 1st year of life. The characteristic feature of the disease include elevated intraocular pressure (IOP), enlargement of the globe (buphthalmos), edema, and opacification of the cornea with rupture of Descemet's membrane, thinning of the anterior sclera and atrophy of the iris, anomalously deep anterior chamber, progressive optic atrophy, photophobia, blepharospasm, and excessive tearing (hyperlacrimation). ${ }^{42}$ Autosomal recessive and simplex forms of the disease exists; the disease is mapped to 3 chromosomal loci ${ }^{43,44}$ of which GLC3A loci mapped to CYP1B1 gene in 2p2145 is widely studied for mutations. CYP1B1 mutations are seen in familial PCG cases with the frequency ranging from 20 to 100 percent depending on the ethnicity $^{46-51}$ and decreases to 10 to 15 percent in simpler cases of PCG. ${ }^{52}$

The first gene to be directly implicated in the pathogenesis of primary congenital glaucoma is CYP1B1 and has been identified by positional cloning approach. CYP1B1 was mapped to the 2p21 region (GLC3A locus; OMIM 231300) by in situ hybridization high-resolution mapping placed this gene within the GLC3A candidate region. The gene has 3 coding regions of which exon 1 is untranslated and the remaining exons codes for a 543 amino acid containing CYP1B1 protein. ${ }^{53}$ The exact mechanism of the CYP1B1 protein in glaucoma pathology is not clear till date. However, it has been proposed that a cytochrome P450-dependent arachidonate metabolite inhibits $\mathrm{Na}^{+}-\mathrm{K}^{+}$-ATPase in the cornea in regulating corneal transparency and aqueous humor secretion. ${ }^{54}$ Till date 54 CYP1B1 gene mutations, majority of which are missense/nonsense changes are reported world wide in PCG patients. ${ }^{55}$ However, animal models have showed interplay of modifier genes in the congenital glaucoma phenotypes. The CYP1B1-animal model has ocular drainage structure abnormalities resembling that of human primary congenital glaucoma patients and demonstrated a modifier role for the tyrosine gene through the tyrosinase/Ldopa pathway.

\section{DEVELOPMENTAL GLAUCOMA GENES}

Developmental glaucoma (DG) occurs due to the malformation of the anterior segment tissues of the eye (anterior segment 
dysgenesis; ASD) 50 percent of the ASD patients develop glaucoma along with elevated intraocular pressure. ${ }^{56}$ Animal model studies had helped in the current knowledge on the genetics of DG. The candidate genes for DG belong to group of transcription factors from the paired box homeodomain and transforming growth factor superfamily. The levels of these transcription factors that alter the effect on the regulating gene are postulated to be causative of the glaucoma effect observed in the glaucoma patients. The mutant proteins are associated with an early onset glaucoma that is characterized by developmental defects of the anterior segment of the eye as seen in autosomal dominant disorders like iris hypoplasia, iridogoniodysgenesis syndrome, ARS, and others. The variable expressivity and incomplete penetrance of the disease, a complex inheritance pattern is suggested despite of many autosomal dominant and recessive models of the disease. ${ }^{57,58}$

\section{PRIMARY CLOSURE-ANGLE GLAUCOMA (PACG)}

PACG is characterized by closure of part of the filtration angle; this happens due to iris apposition to the trabecular meshwork (TM) and it occurs in individuals with crowded anterior chamber anatomical structures. The risk factors for PACG include ethnicity, sex (females with 3 to 4 times high risk than men), hyperopia, anatomical factors like small corneal diameter, thickened lens, small axial length and shallow anterior chamber ( $<1.5 \mathrm{~mm}$ normal: $2.0 \mathrm{~mm}$ ) seen in hyperopic patients. A strong role for genetic factors predisposing the 1st and 2nd degree relatives of the PACG patients has been reported particularly for the anatomical risk factors. Despite these facts, there are literally no reports available on the causative or predisposing genes/chromosomal loci for the disease. PACG has wide ethnic preponderance and found more commonly in Eskimos, Mongoloids, Indians, Chinese and other Asian descendents compared to Caucasians. Heritability for the axial anterior chamber depth (ACD), one of the risk factors for PACG is 70 percent. It was first suggested that an autosomal dominant gene transmits PACG. Alsbirk et al observed that the 1st and 2nd degree relatives of the PACG patients have relatively shallow chamber and an increased prevalence of the disease in the sibs; thus, emphasizing a strong role for genetic factors in the pathology of the disease. In an analysis of the ACD between the Mongoloids and Chinese Singaporeans, Aung et al has shown that the shallow anterior chamber confers significant risk for angle-closure in East Asians. Similarly, the south Indian patients' eyes of PACG and occludable angle patients had significantly shorter axial lengths, shallower anterior chambers and greater lens thickness compared to the normal control group. ${ }^{59}$ In spite of these facts, the genetics of PACG is yet to be identified. Genomewide scan by Aung et al in a 2 generation autosomal dominant family ${ }^{60}$ has shown a suggestive linkage for the marker D10S192 but gene has not been identified. There are few reports on MYOC gene status in the PACG patients that were done with the rationale on the existence of comparable ultrastructural changes in the TM tissue in both POAG and PACG patients. ${ }^{61,62}$

\section{UNRAVELING THE COMPLEXITY OF GLAUCOMA ETIOLOGY BY NOVEL METHODS}

These information are not suffice to understand the biologic etiology of glaucoma. Since most of the adult onset form of glaucoma like POAG, NTG, PACG, pseudoexfoliation glaucoma, etc. are inherited as complex traits ${ }^{63}$ and conventional genomewide search for complex diseases has its own limitations due to: (i) genetic heterogeneity, (ii) multiple genetic, environmental factors and their interactions, (iii) clinical heterogeneity and lack of standard universal classifications leading to imprecise definition of the phenotypes, (iv) inadequate power that is limited by the size of the pedigrees, (v) limitations of the standard microsatellite markers to extract the sufficient genetic information, approaches like animal models, whole genome association (SNPs) methods, ordered subset analysis, quantitative trait mapping, etc. are better. Model free nonparametric approaches have been adopted recently by different groups in quest of finding the disease causing/risk predisposing loci for glaucoma. These methods include quantitative trait loci mapping (QTL), validating the observations from animal models of glaucoma, genomewide scan, ordered subset analysis (OSA), etc.

Elevated intraocular pressure has always been the contributing risk factor for the onset of the adverse glaucoma outcome. The direct relation between elevated IOP in glaucoma has also been doubted as there are people who develop the optic disk changes despite a normal IOP. Animal models have also suggested that elevated IOP has a causative role in the RGC apoptosis through the effect on extracellular matrix. The role of myocilin in IOP elevation through its dominant negative effect has been proved by many cell culture studies. Apart from these approaches QTL mapping, OSA and animal models have given new insight into the possible genes conferring susceptibility to IOP elevation.

\section{QTL MAPPING AND OSA IN GLAUCOMA GENETICS}

Quantitative trait loci mapping have been used a powerful method in mapping the loci for IOP, cup to disc ratio, etc. in glaucoma. A genome wide scan through the Beaver Dam eye study has identified 7 regions of interest on chromosomes 2, 5, $6,7,12,15$, and 19 . It is quite interesting to note that 2 of these regions on chromosome 2 and 19 have colocalized with the region for blood pressure. ${ }^{64,65}$ Similarly, Charlesworth et $a l^{65}$ have mapped the chromosomal region 10q22 with a maximum load score of 3.3 for IOP variance in a large Australian population and it is noteworthy to mention that the loci for systemic hypertension also lie in the same region. 
OSA is another approach used for gene mapping in complex diseases like diabetes, AMD, autism ${ }^{66}$ that has also been used to map the glaucoma genes to overcome the interfering problems of molecular, genetic and clinical heterogeneity. In the approach of OSA, the families for linkage analysis are first identified and classified based on the phenotypic variable (e.g. elevated IOP, cup to disc ratio, age of onset, etc.) to ensure homogeneity of the sample to be analyzed for evidence of linkage. Thus, by subset of families with greater evidence of linkage are determined and the candidate genes in the linked loci are further analyzed for its possible role in the disease. ${ }^{67}$ By OSA linkage chromosomal loci 15q11-13 (GLC1I) was initially identified in an early adult onset open angle glaucoma ${ }^{68}$ family that was also confirmed in an independent sample of 167 individuals in 25 multiplex European descent, OAG families with middle-aged mean age at diagnosis.

\section{ANIMAL MODELS IN GLAUCOMA}

The current knowledge on glaucoma biology has been enhanced by experimental animal models that includes mice, rats, primates, pigs, etc. Of these the primates are the ideal models to study the glaucoma pathology but have their own constrains on availability, cost of the experimentation, etc. ${ }^{69}$ The mice models are selected due to the advantage offered by the availability of mutant and transgenic strains mimicking specific aspects of glaucoma. Animal models worth mentioning in this context are the C57BL/6J (OPTN mutants), Col1a1 mutant mice models for POAG, DBA/2J mice for pigment dispersion syndrome glaucoma (mutant for tyrosinase related protein (Tyrp $1^{\mathrm{b}}$ ) and glyprotein nmb gene $\left(\mathrm{Gpnmb} \mathrm{b}^{\mathrm{R} 150 \mathrm{X}}\right)$, transgenic mice and rat models for myocilin gene mutations, anterior segment dysgenesis and developmental glaucoma; such models are useful not only to understand the pathophysiology of the disease but also for therapeutic experiments. $^{69}$

Insights from animal models of glaucoma have also shown that mild developmental defects of angle and other tissues involved in aqueous humor outflow regulation also results in the elevated IOP. Some of the ASD and developmental glaucoma genes (PAX6, CYP1B1, FOXc1, etc.) correlated with increased IOP like BMP4, CYP1B1, FOXC1, etc. in animal models are well correlated for similar effects in humans too. An insight into the genes regulating the aqueous humor inflow is also gained through animal models: SLC4A4 (sodium bicarbonate cotransporter), adenosine 3 receptor, aquaporin water channel (Aqp1 and Aqp4) have been studied in mutant mice and found to have an effect on the production of aqueous humor and thus on the IOP levels. Of these genes, mutations in SLC4A4 gene are shown in patients with ocular hypertension and renal defects. $^{69}$

It is observed that both MYOC and CYP1B1 gene mutations contribute to POAG/PCG pathology suggesting a genetic modifier effect by multiple interacting genes (one of the salient feature of complex inheritance). The tryrosinase (tyr) gene is identified as a modifier gene for angle development in cyp1b1 and Foxc1 deficient mice.

A combination of events like ischemia, excitotoxicity, autoimmunity, axonal injury, glial activity, etc. has been proposed to vary an individual's susceptibility for retinal ganglion cell death. The TNF $\alpha$, IGF, APOE, OPA1 genes have been studied in animal models for their role in RGC death. ${ }^{69}$ These genes are also studied for their possible association with POAG in different populations.

\section{CONCLUSION}

Genetic screening in glaucoma as discussed so far suggests the extent of genetic heterogeneity contributing to the disease. Thus, we have acquired only limited knowledge on the possible genes involved in glaucoma pathology. Several interacting/ modifying/candidate genes have been identified that contribute to the disease. The genes that are implicated in different animal models of glaucoma could be studied in human models to validate and confirm their role integrating different genetic approaches and corroborating these insights in human samples will be the future direction for us to have a complete portrait on the genetic and molecular etiology of glaucoma.

\section{ACKNOWLEDGEMENT}

Chennai Willingdon Corporate Foundation, Chennai,India.

\section{REFERENCES}

1. Resnikoff S, Pascolini D, Etya'ale D, Kocur I, Pararajasegaram R, Pokharel GP, Mariotti SP. Global data on visual impairment in the year 2002. Bull World Health Organ 2004;82:844-51.

2. Charlesworth JC, Dyer TD, Stankovich JM, Blangero J, Mackey DA, Craig JE, Green CM, Foote SJ, Baird PN, Sale MM. Linkage to 10q22 for maximum intraocular pressure and 1p32 for maximum cup-to-disc ratio in an extended primary openangle glaucoma pedigree. Invest Ophthalmol Vis Sci 2005;46:3723-9.

3. Klein BE, Klein R, Lee KE. Heritability of risk factors for primary open-angle glaucoma: the Beaver Dam Eye Study. Invest Ophthalmol Vis Sci 2004;45:59-62.

4. Ningli WZ, Tiancai Y, Qiang Y, Mingying L, Meihua L. Studies of primary angle closure glaucoma in China.Yan Ke Xue Bao 1997;13(3):120-4.

5. Dandona L, Dandona R, Mandal P, Srinivas M, John RK, McCarty CA, Rao GN. Angle closure glaucoma in an urban population in Southern India. The Andhra Pradesh Eye Disease Study. Ophthalmology 2000;107:1710-6.

6. Salmon JF, Mermoud A, Ivey A, Swanevelder SA, Hoffman M. The prevalence of primary angle closure glaucoma and open angle glaucoma in Mamre, western Cape, South Africa. Arch Ophthalmol 1993;111:1263-9. 
7. Foster JP. Advances in the understanding of primary angle closure as a cause of glaucomatous optic neuropathy. Community Eye Health 2001;14:37-9.

8. Alsbirk PH. Anterior chamber depth and primary angle-closure glaucoma. II. A genetic study. Acta Ophthalmol (Copenh) 1975;53:436-49.

9. Alsbirk PH. Primary angle-closure glaucoma. Oculometry, epidemiology, and genetics in a high risk population. Acta Ophthalmol Suppl 1976;127:5-31.

10. Gong G, Kosoko-Lasaki S, Haynatzki G, Lynch HT, Lynch JA, Wilson MR.Inherited, familial and sporadic primary open-angle glaucoma. J Natl Med Assoc 2007;99(5):559-63.

11. Sheffield VC, Stone EM, Alward WL, Drack AV, Johnson AT, Streb LM, Nichols BE.Genetic linkage of familial open angle glaucoma to chromosome 1q21-q31. Nat Genet 1993;4:47-50.

12. Stone EM, Fingert JH, Alward WL, Nguyen TD, Polansky JR, Sunden SL, Nishimura D, Clark AF, Nystuen A, Nichols BE, Mackey DA, Ritch R, Kalenak JW, Craven ER, Sheffield VC. Identification of a gene that causes primary open angle glaucoma. Science 1997;31;275(5300):668-70.

13. Ueda J, Yue BY. Distribution of myocilin and extracellular matrix components in the corneoscleral meshwork of human eyes. Invest Ophthalmol Vis Sci 2003;44:4772-9.

14. Nguyen TD, Chen P, Huang WD, Chen H, Johnson D, Polansky JR. Gene structure and properties of TIGR, an olfactomedinrelated glycoprotein cloned from glucocorticoid-induced trabecular meshwork cells. J Biol Chem 1998;273:6341-50.

15. Ueda J, Wentz-Hunter K, Yue BY. Distribution of myocilin and extracellular matrix components in the juxtacanalicular tissue of human eyes. Invest Ophthalmol Vis Sci 2002;43:1068-76.

16. Gong G, Kosoko-Lasaki O, Haynatzki GR, Wilson MR.Genetic dissection of myocilin glaucoma. Hum Mol Genet 2004;13 (Spec no 1):R91-102.

17. Polansky JR, Fauss DJ, Chen P, Chen H, Lutjen-Drecoll E, Johnson D, Kurtz RM, Ma ZD, Bloom E, Nguyen TD.Cellular pharmacology and molecular biology of the trabecular meshwork inducible glucocorticoid response gene product. Ophthalmologica 1997;211:126-39.

18. Alward WL, Fingert JH, Coote MA, Johnson AT, Lerner SF, Junqua D, Durcan FJ, McCartney PJ, Mackey DA, Sheffield VC, Stone EM. Clinical features associated with mutations in the chromosome 1 open angle glaucoma gene. N Engl J Med 1998;338:1022-102.

19. Zimmerman CC, Lingappa VR, Richards JE, Rozsa FW, Lichter PR, Polansky JR. A trabecular meshwork glucocorticoid response (TIGR) gene mutation affects translocational processing. Mol Vis 1999;5:19.

20. Sripriya S, Uthra S, Sangeetha R, George RJ, Hemamalini A, Paul PG, Amali J, Vijaya L, Kumaramanickavel G. Low frequency of myocilin mutations in Indian primary open-angle glaucoma patients. Clin Genet 2004;65:333-7.

21. Caballero M, Borras T. Inefficient processing of an olfactomedindeficient myocilin mutant: potential physiological relevance to glaucoma. Biochem Biophys Res Commun 2001;282:662-70.

22. Gobeil S, Rodrigue MA, Moisan S, Nguyen TD, Polansky JR,
Morissette J, Raymond V. Intracellular sequestration of heterooligomers formed by wild-type and glaucoma-causing myocilin mutants. Invest Ophthalmol Vis Sci 2004;45:3560-7.

23. Joe MK, Sohn S, Hur W, Moon Y, Choi YR, Kee C. Accumulation of mutant myocilins in ER leads to ER stress and potential cytotoxicity in human trabecular meshwork cells. Biochem Biophys Res Commun 2003;312:592-600.

24. Liu Y, Vollrath D. Reversal of mutant myocilin non-secretion and cell killing: implications for glaucoma. Hum Mol Genet 2004;13:1193-204.

25. Ueda J, Wentz-Hunter K, Yue BY. Distribution of myocilin and extracellular matrix components in the juxtacanalicular tissue of human eyes. Invest Ophthalmol Vis Sci 2002;43:1068-76.

26. Rezaie T Child A, Hitchings R, Brice G, Miller L, Coca-Prados M, Heon E, Krupin T, Ritch R, Kreutzer D, Crick RP, Sarfarazi M. Adult-onset primary open-angle glaucoma caused by mutations in optineurin. Science 2002;295:1077-9.

27. Willoughby CE, Chan LL, Herd S, Billingsley G, Noordeh N, Levin AV, Buys Y, Trope G, Sarfarazi M, Heon E.Defining the pathogenicity of optineurin in juvenile open-angle glaucoma. Invest Ophthalmol Vis Sci 2004;45:3122-30.

28. Li Y, Kang J, Horwitz MS. Interaction of an adenovirus E3 14.7-kilodalton protein with a novel tumor necrosis factor alphainducible cellular protein containing leucine zipper domains. Mol Cell Biol 1998;18:1601-10.

29. Moreland RJ, Dresser ME, Rodgers JS, Roe BA, Conaway JW, Conaway RC, Hanas JS. Identification of a transcription factor IIIA-interacting protein. Nucleic Acids Res 2000;28:1986-93.

30. Schwamborn K, Weil R, Courtois G, Whiteside ST, Israel A.Phorbol esters and cytokines regulate the expression of the NEMO-related protein, a molecule involved in a NF-kappa-Bindependent pathway. J Biol Chem 2000;275:22780-9.

31. Sarfarazi M, Rezaie T. Optineurin in primary open angle glaucoma. Ophthalmol Clin North Am 2003;16:529-4.

32. Funayama T, Ishikawa K, Ohtake Y, Tanino T, Kurosaka D, Kimura I, Suzuki K, Ideta H, Nakamoto K, Yasuda N, Fujimaki T, Murakami A, Asaoka R, Hotta Y, Tanihara H, Kanamoto T, Mishima H, Fukuchi T, Abe H, Iwata T, Shimada N, Kudoh J, Shimizu N, Mashima Y.Variants in optineurin gene and their association with tumor necrosis factor-alpha polymorphisms in Japanese patients with glaucoma. Invest Ophthalmol Vis Sci 2004,45:4359-67.

33. Leung YF Fan BJ, Lam DS, Lee WS, Tam PO, Chua JK, Tham CC, Lai JS, Fan DS, Pang CP. Different optineurin mutation pattern in primary open-angle glaucoma. Invest Ophthalmol Vis Sci 2003;44:3880-4.

34. Alward WL, Kwon YH, Kawase K, Craig JE, Hayreh SS, Johnson AT, Khanna CL, Yamamoto T, Mackey DA, Roos BR, Affatigato LM, Sheffield VC, Stone EM. Evaluation of optineurin sequence variations in 1,048 patients with open-angle glaucoma. Am J Ophthalmol 2003;136:904-10.

35. Melki R, Belmouden A, Akhayat O, Brezin A, Garchon HJ. The M98K variant of the Optineurin (OPTN) gene modifies initial intraocular pressure in patients with primary open angle glaucoma. J Med Genet 2003;40:842-4. 
36. Aung T, Ebenezer ND, Brice G, Child AH, Prescott Q, Lehmann OJ, Hitchings RA, Bhattacharya SS. Prevalence of optineurin sequence variants in adult primary open angle glaucoma: implications for diagnostic testing. J Med Genet 2003;40:101.

37. Aung T, Rezaie T, Okada K, Viswanathan AC, Child AH, Brice G, Bhattacharya SS, Lehmann OJ, Sarfarazi M, Hitchings RA. Clinical features and course of patients with glaucoma with the E50K mutation in the optineurin gene. Invest Ophthalmol Vis Sci 2005;46:2816-22.

38. Chalasani ML, Radha V, Gupta V, Agarwal N, Balasubramanian D, Swarup G. A glaucoma-associated mutant of optineurin selectively induces death of retinal ganglion cells which is inhibited by antioxidants. Invest Ophthalmol Vis Sci 2007;48(4):160714.

39. Vittitow J, Borras T Expression of optineurin, a glaucoma-linked gene, is influenced by elevated intraocular pressure. Biochem Biophys Res Commun 2002;298:67-74.

40. Monemi S, Spaeth G, DaSilva A, Popinchalk S, Ilitchev E, Liebmann J, Ritch R, Heon E, Crick RP, Child A, Sarfarazi M, Identification of a novel adult-onset primary open-angle glaucoma (POAG) gene on5q22.1; Human Molecular Genetics 2005;14(6):725-33.

41. Mao M, Biery MC, Kobayashi SV, et al. T lymphocyte activation gene identification by coregulated expression on DNA microarrays. Genomics 2004;83:989-99.

42. Francois J. Congenital glaucoma and its inheritance. Ophthalmologica 1980;181:61-73.

43. Akarsu AN, Turacli ME, Aktan SG, Barsoum-Homsy M, Chevrette L, Sayli BS, Sarfarazi M. A second locus (GLC3B) for primary congenital glaucoma (Buphthalmos) maps to the 1p36 region. Hum Mol Genet 1996;5:1199-203.

44. Stoilov SM. The third genetic locus. (GLC3C) for primary congenital glaucoma (PCG) maps to chromosome 14q24.3. Annual Meeting Abstract Search and Program Planner, 2002.

45. Sarfarazi M, Akarsu AN, Hossain A, Turacli ME, Aktan SG, Barsoum-Homsy M, Chevrette L, Sayli BS. Assignment of a locus (GLC3A) for primary congenital glaucoma (Buphthalmos) to 2 p21 and evidence for genetic heterogeneity. Genomics 1995;30:171-7.

46. Plasilova M, Stoilov I, Sarfarazi M, Kadasi L, Ferakova E, Ferak V. Identification of a single ancestral CYP1B1 mutation in Slovak Gypsies (Roms) affected with primary congenital glaucoma. J Med Genet 1999;36:290-4.

47. Bejjani BA, Lewis RA, Tomey KF, Anderson KL, Dueker DK, Jabak M, Astle WF, Otterud B, Leppert M, Lupski JR. Mutations in CYP1B1, the gene for cytochrome P4501B1, are the predominant cause of primary congenital glaucoma in Saudi Arabia. Am J Hum Genet 1998;62:325-33.

48. Panicker SG, Reddy AB, Mandal AK, Ahmed N, Nagarajaram HA, Hasnain SE, Balasubramanian D. Identification of novel mutations causing familial primary congenital glaucoma in Indian pedigrees. Invest Ophthalmol Vis Sci 2002;43:1358-66.

49. Stoilov IR, Costa VP, Vasconcellos JP, Melo MB, Betinjane AJ, Carani JC, Oltrogge EV, Sarfarazi M. Molecular genetics of primary congenital glaucoma in Brazil. Invest Ophthalmol Vis Sci 2002;43:1820-7.
50. Mashima Y, Suzuki Y, Sergeev Y, Ohtake Y, Tanino T, Kimura I, Miyata H, Aihara M, Tanihara H, Inatani M, Azuma N, Iwata T, Araie M. Novel cytochrome P4501B1 (CYP1B1) gene mutations in Japanese patients with primary congenital glaucoma. Invest Ophthalmol Vis Sci 2001;42:2211-6.

51. Ramprasad VL, George RJ, Sripriya S, Nirmaladevi J, Vijaya L, Kumaramanickavel G. Molecular genetic analysis of a consanguineous south Indian family with congenital glaucoma: relevance of genetic testing and counseling. Ophthalmic Genet 2007;28(1):17-24.

52. Curry SM, Daou AG, Hermanns P, Molinari A, Lewis RA, Bejjani BA. Cytochrome P4501B1 mutations cause only part of primary congenital glaucoma in Ecuador. Ophthalmic Genet 2004;25:3-9.

53. Stoilov I, Akarsu AN, Sarfarazi M: Identification of three different truncating mutations in cytochrome P4501B1 (CYP1B1) as the principal cause of primary congenital glaucoma (Buphthalmos) in families linked to the GLC3A locus on chromosome 2p21. Hum Mol Genet 1997;6:641-7.

54. Schwartzman ML, Balazy M, Masferrer J, Abraham NG, McGiff JC, Murphy RC: 12(R)-hydroxyicosatetraenoic acid: A cytochrome-P450- dependent arachidonate metabolite that inhibits $\mathrm{Na}^{+}, \mathrm{K}^{+}$-ATPase in the cornea. Proc Natl Acad Sci USA 1987;84:8125-9.

55. http://www.hgmd.cf.ac.uk/ac/gene.php? gene = CYP1B1

56. Gould DB, Smith RS, John SW. Anterior segment development relevant to glaucoma. Int J Dev Biol 2004,48:1015-29.

57. Strungaru MH, Dinu I, Walter MA Genotype-phenotype correlations in Axenfeld-Rieger malformation and glaucoma patients with FOXC1 and PITX2 mutations. Invest Ophthalmol Vis Sci 2007;48(1):228-37.

58. Cella W, de Vasconcellos JP, de Melo MB, Kneipp B, Costa FF, Longui CA, Costa VP. Structural assessment of PITX2, FOXC1, CYP1B1, and GJA1 genes in patients with AxenfeldRieger syndrome with developmental glaucoma. Invest Ophthalmol Vis Sci 2006;47(5):1803-9.

59. George R, Paul PG, Baskaran M, Ramesh SV, Raju P, Arvind H, McCarty C, Vijaya L. Ocular biometry in occludable angles and angle closure glaucoma: a population based survey. $\mathrm{Br} \mathrm{J}$ Ophthalmol 2003;87:399-402.

60. Aung T Bowman R, Chew PT, Seah SK , Ang LP, Yap E, Lehmann OJ, Dearlove A, Hitchings RA, Bhattacharya SS Genome-wide linkage scan for primary angle closure glaucoma. Invest Ophthalmol Vis Sci 2003;44:3224.

61. Vincent AL, Billingsley G, Buys Y, Levin AV, Priston M, Trope G, Williams-Lyn D, Heon E. Digenic inheritance of early-onset glaucoma: CYP1B1, a potential modifier gene. Am J Hum Genet 2002;70:448-60

62. Aung T, Nolan WP, Machin D, Seah SK, Baasanhu J, Khaw PT, Johnson GJ, Foster PJ. Anterior chamber depth and the risk of primary angle closure in 2 East Asian populations. Arch Ophthalmol 2005;123:527-32.

63. Libby RT, Gould DB, Anderson MG, John SW. Complex genetics of glaucoma susceptibility. Annu Rev Genomics Hum Genet 2005;6:15-44. 
64. Duggal P, Klein AP, Lee KE, Klein R, Klein BE, Bailey-Wilson JE. Identification of novel genetic loci for intraocular pressure: a genomewide scan of the Beaver Dam Eye Study. Arch Ophthalmol 2007;125(1):74-9.

65. Charlesworth JC, Dyer TD, Stankovich JM, Blangero J, Mackey DA, Craig JE, Green CM, Foote SJ, Baird PN, Sale MM. Linkage to 10q22 for maximum intraocular pressure and 1p32 for maximum cup-to-disc ratio in an extended primary openangle glaucoma pedigree. Invest Ophthalmol Vis Sci 2005;46:3723-9.

66. Nemesure B, Wu SY, Hennis A, Leske MC. Factors related to the 4-year risk of high intraocular pressure: the Barbados eye studies. Arch Ophthalmol 2003;121:856-62.
67. Allingham RR, Wiggs JL, Hauser ER, Larocque-Abramson KR, Santiago-Turla C, Broomer B, Del Bono EA, Graham FL, Haines JL, Pericak-Vance MA, Hauser MA. Early adult-onset POAG linked to 15q11-13 using ordered subset analysis Invest Ophthalmol Vis Sci 2005;46(6):2002-5.

68. OWoodroffe A, Krafchak CM, Fuse N, Lichter PR, Moroi SE, Schertzer R, Downs CA, Duren WL, Boehnke M, Richards JE. Ordered subset analysis supports a glaucoma locus at GLC1I on chromosome 15 in families with earlier adult age at diagnosis. Exp Eye Res 2006;82(6):1068-74 (Epub 2005 Nov 18).

69. John SW Mechanistic insights into glaucoma provided by experimental genetics the cogan lecture. Invest Ophthalmol Vis Sci 2005;46(8):2649-61. 